OPEN ACCESS

Edited by:

Mario Mairal,

Stellenbosch University, South Africa

Reviewed by:

Alejandro González Fernández De

Castro,

Autonomous University of Madrid,

Spain

Luis Navarro,

University of Vigo, Spain

${ }^{*}$ Correspondence:

Martí March-Salas

martimarchsalas@gmail.com

${ }^{\dagger}$ These authors have contributed equally to this work

Specialty section:

This article was submitted to

Conservation and Restoration

Ecology,

a section of the journa

Frontiers in Ecology and Evolution

Received: 28 September 2020

Accepted: 26 March 2021

Published: 22 April 2021

Citation:

deCastro-Arrazola I,

March-Salas M and Lorite J (2021)

Assessment of the Potential Risk

of Rock-Climbing for Cliff Plant

Species and Natural Protected Areas

of Spain. Front. Ecol. Evol. 9:611362.

doi: 10.3389/fevo.2021.611362

\section{Assessment of the Potential Risk of Rock-Climbing for Cliff Plant Species and Natural Protected Areas of Spain}

\author{
Indradatta deCastro-Arrazola ${ }^{1 \dagger}$, Martí March-Salas ${ }^{2 *}$ and Juan Lorite ${ }^{3}$ \\ 1 Department of Biogeography and Global Change, Museo Nacional de Ciencias Naturales (MNCN-CSIC), Madrid, Spain, \\ ${ }^{2}$ Plant Evolutionary Ecology, Institute of Ecology, Evolution and Diversity, Goethe University Frankfurt, Frankfurt am Main, \\ Germany, ${ }^{3}$ Department of Botany, Faculty of Sciences, University of Granada (UGR), Granada, Spain
}

In recent years, the popularity of rock-climbing has grown tremendously, setting an increasing pressure on cliff habitats. Climbing may be particularly harmful in the Mediterranean biome due to its appropriate environmental conditions for climbing. A few studies have identified the effect of climbing on plant diversity at a small-scale (namely locally or even just in specific climbing areas). However, no studies exist assessing the potential risk of rock-climbing on a broad-scale (e.g., regional or national). The study aims to identify the priority locations and priority cliff plant species in Spain to focus future study efforts. Spain was selected because it is a plant biodiversity hotspot, with a great diversity of endemic and endangered species, and one of the most popular destinations for climbers. We used a geographic information system-based approach to model the spatial concurrence among Spanish climbing areas (and climbing intensity), natural protected areas (NPAs), and distribution of threatened cliff plants (and their IUCN threat category). We found that $53.5 \%$ of climbing areas in Spain are located within a NPA, most of them falling into NPAs of medium protection level. We mapped 151 threatened cliff plants, identifying four medium priority Mediterranean locations and eight priority species in which future research efforts should be focused. High-priority study locations are absent in Spain according to our spatial modeling. For the first time on a national scale, this study identifies areas in which climbing represents a potential threat for cliff habitats and threatened plants. These findings contribute to designing field studies on the effects of rock-climbing on Mediterranean cliffs, laying the groundwork for a sustainable, yet challenging, balance between the protection of these unique habitats and rock-climbing.

Keywords: biodiversity conservation, Mediterranean plants, priority natural areas, rock-climbing impact, spatial analysis, threatened cliff plant species, IUCN protection categories

\section{INTRODUCTION}

Human activities are changing ecosystems worldwide, being a major threat to the biodiversity of the planet (Vitousek et al., 1997; Newbold et al., 2015). To prevent further biodiversity loss, today conservation efforts, concentrated on natural protection areas, must not only focus on conserving iconic landscapes and wildlife but also consider a framework of social welfare 
(Watson et al., 2014). Sports activities in natural areas such as hiking, trail running, and rock-climbing contribute to this social welfare and increased exponentially in recent decades (Cordell, 2012; American Alpine Club Report [AAC], 2019). These activities are now considered to be a key aspect of people's wellbeing and leisure, but, at the same time, pose a potential threat to the natural environment where they take place (Burgin and Hardiman, 2012).

Among these outdoor sports activities, rock-climbing represents a challenge for the management and conservation of natural protected areas (NPAs), especially now that its popularity has grown tremendously and climbing represents a motivation for tourism (Caber and Albayrak, 2016). Currently, there are more than 1.6 million active climbers in Europe and forecasts show a huge increase in the following 30 years (Hanemann, 2000; Cordell, 2012; American Alpine Club Report [AAC], 2019)-especially after the presence of climbing at the Tokyo Olympic Games, which can raise interest on this discipline. The inclusion of indoor climbing at the Olympic Games reflects the evolution of climbing in the last century, from a niche sport only practiced by a minority to a popular sport, made more accessible through the increasing number of indoor climbing gyms (UIAA, 2000, 2014). However, the transition from climbing in gyms to the natural environment is often undertaken with little awareness of conservation and, for instance, fails to consider cliff organisms in a climbing route (UIAA, 2000, 2014). Such a trend could accelerate a loss of biodiversity, the degradation of cliff habitats, and even lead to a loss of recreational amenities (Burgin and Hardiman, 2012).

The effect of rock-climbing may be especially harmful to plants, due to their inability to rapidly move away from unfavorable conditions and disturbances (unlike birds nesting on cliffs; e.g., Larson et al., 2000). Despite their roughness and the harsh conditions for the plants' growth, cliff habitats can support a great diversity of plant species, harboring a high amount of endemisms and endangered species (Larson et al., 2000; Lavergne et al., 2003). Thus, rock-climbing poses a potential threat, not only for the diversity of cliff vegetation but also for unique and threatened plant species (Larson et al., 2000). However, only a few local small-scale field studies exist on the effect of rockclimbing on cliff plant species (e.g., Clark and Hessl, 2015; Lorite et al., 2017; March-Salas et al., 2018; Schmera et al., 2018; Strumia et al., 2020), and these have not always been properly conducted (Holzschuh, 2016). Moreover, these isolated case studies did not state the criteria used to select study sites, leading to an unknown relevance of the sites for conservation purposes. Thus, studies assessing the potential risk of rock-climbing for threatened plant species at wider spatial scales are needed to design more informative and successful field studies in the future.

The assessment of the effect of rock-climbing on cliff plant species is especially relevant for Mediterranean cliffs (Lorite et al., 2017; March-Salas et al., 2018). The Mediterranean biome is a plant biodiversity hotspot (Myers et al., 2000; Médail and Diadema, 2009), harboring a large amount of endangered and endemic cliff plant species (Larson et al., 2000). This is especially true in Spain (mostly Mediterranean) since it is one of the most biodiverse countries in the European Union, and has been designated as a key territory for conservation (National Biodiversity Strategy, 2020), and holds the highest number of protected areas in Europe (covering 27\% of its land area; Ministerio para la Transición Ecológica [MITECO], 2018; UNESCO, 2020). These protected areas are divided into different degrees of protection (see Supplementary Table 1), they are meant to protect rare and threatened animal and plant species and serve as fundamental tools for ecosystem management and conservation. Moreover, Spain is one of the most popular international rock-climbing destinations due to the appropriate environmental conditions for rock-climbing and the great amount of well-developed climbing crags (i.e., climbing locations, the basic unit grouping climbing routes). As a result, there are more than 1,000 climbing crags in Spain (Martos, 2018) and it is estimated that there are more than 200,000 climbers with at least 100,000 of these climbers having emerged in the last decade (Lorite et al., 2017). Thus, the combination of these three elements (i.e., a plant biodiversity hotspot, an outstanding percentage of protected surface, and a well-established and growing rock-climbing destination) makes Spain ideal for a broad-scale study of the potential risk of rock-climbing for cliff plant species.

This study aims to identify priority areas and species for future in-depth field studies of the potential risks posed by rock-climbing for plant biodiversity. Specifically, we (1) describe the distribution of rock-climbing in Spain and the NPAs in the country; (2) identify study priority locations based on the distribution of rock-climbing and threatened cliff plant species; and (3) identify study priority species of threatened cliff plant species based on the degree of climbing intensity on each species' distribution.

\section{MATERIALS AND METHODS}

\section{Scope of This Work}

This study covers mainland Spain $\left(494,011 \mathrm{~km}^{2}\right)$ and the Balearic islands $\left(4,992 \mathrm{~km}^{2}\right)$. Geologically, three main units have been recognized (Vera, 2004). (i) Hercinian Basement, composed of metamorphic (gneiss, quartzite, slate, and schist) and plutonic rocks (i.e., granite). (ii) Alpine reliefs, mainly formed by limestone, sandstone, or marls, often with limestone massifs where Hercinian materials also emerged. (iii) River depressions, formed by tertiary or quaternary materials (marl, sand, conglomerates, etc.). The Western part of Spain, mainly composed of Hercinian material, usually presents soft relief, while eastern areas where alpine materials are widely extended form rugged relief (Supplementary Figure 1). This Eastern part is where most of the climbing activity is concentrated. The climate is mainly Mediterranean (or Sub-Mediterranean), a biseasonal climate type in terms of temperature and precipitation, characterized by cool-wet winters with low solar irradiance and hot-dry summers with high solar irradiance and unpredictable environmental conditions (Lionello et al., 2006; March-Salas et al., 2019). Plant diversity is especially high with 6,276 native taxa, being 1,258 species (22.8\%) endemic (Aedo et al., 2017). Here, cliff faces have acted as anthropogenic and environmental 
refuges, resulting in unique habitats with a high number of rare and endemic species (Larson et al., 2000), many of which are threatened by different factors such as high dryness and erosion, intense radiation, and poorly developed soils, etc. (Moreno-Saiz et al., 2003).

This study includes all styles of climbing practiced on natural rock in the natural environment regardless of the safety-gear used: sport climbing (which uses fixed gear on the rock), traditional climbing (which uses removable gear, leaving the rock as it was found), bouldering (which uses no gear on the rock as it takes place on low height rock-boulders), and deep-watersoloing (which uses no safety gear as it takes place over the water). This work includes aid-climbing routes within sport or traditional styles.

\section{Data Sources}

We compiled the locations, climbing popularity, number of routes, and climbing style for all available Spanish climbing crags using specific climbing literature (Martos, 2018). So, due to the subjective nature of the popularity of climbing areas, this variable was retrieved from a single standardized source. Only missing coordinates were completed following approach descriptions in the source, multiple local guidebooks, specific websites, or climbers' comments. We downloaded the polygon layer for the NPAs from the Spanish Ministry website (Ministerio para la Transición Ecológica [MITECO], 2020a). Afterward, we included the equivalence among categories in the NPAs System of Spain and IUCN protected areas classification (Supplementary Table 1).

To compile the cliff threatened species for Spain, we used the Atlas and red book of Spanish threatened vascular flora (Bañares et al., 2004; updated at Ministerio para la Transición Ecológica [MITECO], 2020b-AFA). The selection was made using species' habitat information for species strictly rupicolous or preferential (i.e., mainly rupicolous occasionally living in other habitat types). Information about the habitat was double-checked using reference floras for Spain (Castroviejo, (1986-2019); Blanca et al., 2011). Hence, the final list comprised 151 taxa (Supplementary Table 2). Once the final list was obtained, we used rgbif package (Chamberlain et al., 2016) to download occurrences from Global Biodiversity Information Facility $(\mathrm{GBIF})^{1}$ and taxize package (Chamberlain et al., 2020) to get the gbif IDs of the taxa, using R (version 3.6.1; R Development Core Team, 2019). Specifications for large species dataset compilation followed Waller and Grosjean (2019). We revised the resulting occurrences from GBIF and excluded the ones lacking coordinates or with low precision coordinates (i.e., less than three decimal places).

\section{Data Analysis}

First, we computed "climbing intensity" as a function of two variables describing each climbing crag: climbing popularity and number of routes. Popularity is a categorical variable, ranged from 1 to 6 in our data set (Supplementary Table 3 ) and the number of routes is a continuous variable ranging from 2 to 4000 in our data set. The climbing intensity of each climbing crag was

${ }^{1}$ https://www.gbif.org calculated as popularity $\times \log 10$ (number of routes), where the number of routes was $\log 10$ transformed (thus, ranging 1-4) to have both variables scaled to a similar magnitude.

Second, we rasterized climbing intensity and threatened cliff plant species occurrence data. To do this, we set the grid scale to $10 \times 10 \mathrm{~km}$, fitting best with our information sources (i.e., climbing routes, plant species distribution, and NPAs). In each grid cell, we conservatively selected the maximum climbing intensity of occurring crags and the richness of threatened cliff plant species (as the number of occurring species). Both variables were rescaled dividing them by the maximum value in the whole study area (thus, ranging $0-100 \%$ ).

Third, rasterized variables were overlapped. Point-data of each climbing crag was used to calculate the proportion of routes occurring at each conservation level (i.e., NPAs and their IUCN conservation category correspondence). To evaluate the spatial overlap between climbing intensity and plant richness we added the values of both rasterized variables. A non-spatially explicit replotting of this data led to grid cell prioritization. To identify the threatened cliff plant species, a priority of this study, we selected all grid cells in which a species occurred and computed their mean percentage of climbing intensity (\%). All spatial analyses were performed using packages $\mathrm{rgdal}, \mathrm{sp}$, and raster in R (version 3.6.2; R Development Core Team, 2019).

\section{RESULTS}

\section{Distribution of Rock-Climbing in Spain and Its Natural Protected Areas}

We compiled and used a total of 1,183 climbing crags, gathering 111,384 climbing routes in Spain. Out of these climbing crags, $53.5 \%$ occurred inside any of the 3,304 NPAs in Spain, and the remaining $46.5 \%$ are located in natural areas without any legal protection status.

Climbing crags showed different sizes (i.e., number of routes), climbing popularity, and climbing style. In terms of climbing routes, 65.2\% occurred inside NPAs (Figure 1). However, most of those routes (ca. 90\% falling in any NPAs, $58.3 \%$ of total climbing routes) fell within NPAs of medium protection level (IUCN category IV: "Habitat/species management area"; Figures 1A,B; see Supplementary Table 1 for correspondence with Spanish categories), which is the most frequent IUCN category in the NPAs of Spain (65.5\% of all NPAs). On the contrary, no routes occurred in NPAs of the highest protection level in Spain (i.e., category Ib-Wilderness area; Figures 1A,B; Supplementary Table 1).

The routes in climbing crags occurring at IUCN category IV, were distributed evenly across popularity levels (Figure 1A; see Supplementary Table 3). The distribution of routes is centered on popularity level 4 (described in Martos, 2018, as "Interesting crags for their possibilities, location"), slightly skewed toward popularity level 6 (i.e., "The best crags of the country"; Martos, 2018) and negligible at popularity level 1 (i.e., "Crag with no particular interest"; Martos, 2018). Regarding climbing style, most of the routes in Spain were located at sport climbing crags $(57.5 \%)$ or mixed with traditional climbing routes 

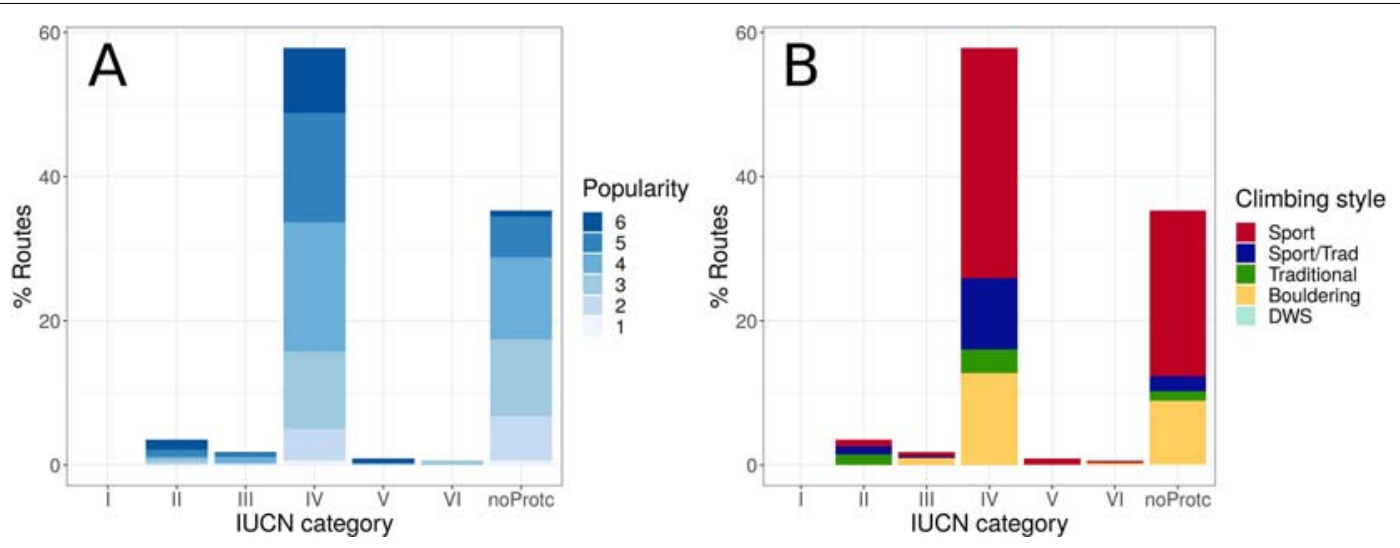

FIGURE 1 | Distribution of climbing routes in Spain across IUCN categories classifying NPAs in which routes are located. (A) Popularity and (B) climbing styles within IUCN categories.

(13.4\%). These proportions were particularly noticeable in IUCN category IV and climbing crags located in natural areas with no protection status (Figure 1B). However, there was a striking higher proportion of traditional climbing within IUCN category II $(41 \%)$ than that in category IV $(5.5 \%)$.

\section{Priority Study Locations}

Climbing crags spread across $78810 \times 10 \mathrm{~km}$ grid cells (Figure 2A). Threatened cliff plant species occurrences were distributed across 1046 grid cells in Spain (Figure 2B), with maximum grid cell richness reaching 12 threatened cliff species. The grid cells in which climbing and threatened cliff plants overlapped (279-35.4\% and $26.7 \%$ of those grid cells with climbing data and richness data, respectively; Figure 2C) were classified into four priority classes (Figure 2D): least priority (both variables below 25\%, blue area), moderate priority (either variable in the $25-50 \%$ range, green area), medium priority (either variable in the $50-75 \%$ range, orange area) and high priority (both variables above $75 \%$, red area). There was no overlap between climbing and threatened cliff species richness in the highest study priority range (75$100 \%)$. However, four grid cells were classified as medium priority locations (50-75\%). These four medium priority grid cells are located within NPAs of IUCN category IV in the municipalities of Gaidovar (Cádiz), Álora (Málaga), Collbató (Barcelona), and Escorca (Mallorca) (for more details, see Supplementary Table 4). In addition, 87 grid cells were classified as moderate priority locations $(25-50 \% ; 31.2 \%$ of all overlapping grid cells), and 188 grid cells (67.4\%) were classified as least priority locations (i.e., with both climbing intensity and/or threatened cliff species richness falling in the $0-$ $25 \%$ range).

\section{Priority Study Species of Threatened Cliff Plant Species}

None of the threatened cliff plant species had a mean climbing intensity greater than 50\% (Figure 3), including those with restricted distributions (i.e., present in less than five grid cells).
However, eight threatened cliff species were present in the range of climbing intensity between 25 and 50\%: Alchemilla pentaphyllea, Alchemilla serratisaxatilis, Galium pulvinatum, Linaria aeruginea subsp. pruinosa, Saxifraga catalaunica, Saxifraga cotyledon, Saxifraga felineri, and Petrocoptis pardoi. All of these threatened cliff species were present in less than 10 grid cells, except $P$. pardoi that occurred in 28 grid cells. According to their IUCN threat category, one of these eight priority species (with climbing intensity between 25 and $50 \%$ ) is considered as Endangered (EN) (G. pulvinatum), four of them as Vulnerable (VU) (A. pentaphyllea, S. cotyledon, S. felineri, and P. pardoi), two of them as Near Threatened species (NT) (S. catalaunica and L. aeruginea subsp. pruinosa), and one as Data Deficient (DD) (A. serratisaxatilis), the latter requiring further fieldwork to confirm its distribution. Finally, 143 threatened cliff plant species were found in the range of climbing intensity between 0 and $25 \%$.

\section{DISCUSSION}

This is the first study to spatially assess the potential risk of rock-climbing for threatened cliff plant species and NPAs. Despite some authors have pointed out the need for a broadscale (e.g., regional, national) assessment to center evaluation and conservation efforts (e.g., Attarian and Keith, 2008), to our knowledge this is the first attempt in doing so. The outcome of this geographic information-based approach has successfully identified locations and threatened species in which there is a higher chance of detecting effects of rock-climbing. This study shows that slightly more than half of the climbing routes in Spain occur within NPAs and most within medium IUCN protection level, sport routes being the most frequent style. Regarding study priority areas, only four locations are above $50 \%$ of the maximum climbing intensity or cliff plant richness in Spain but this work does not show high potential risks of rock-climbing on endangered cliff species, according to the criteria and model considered. Likewise, we highlight the need of studying in-depth with continuous field monitoring 


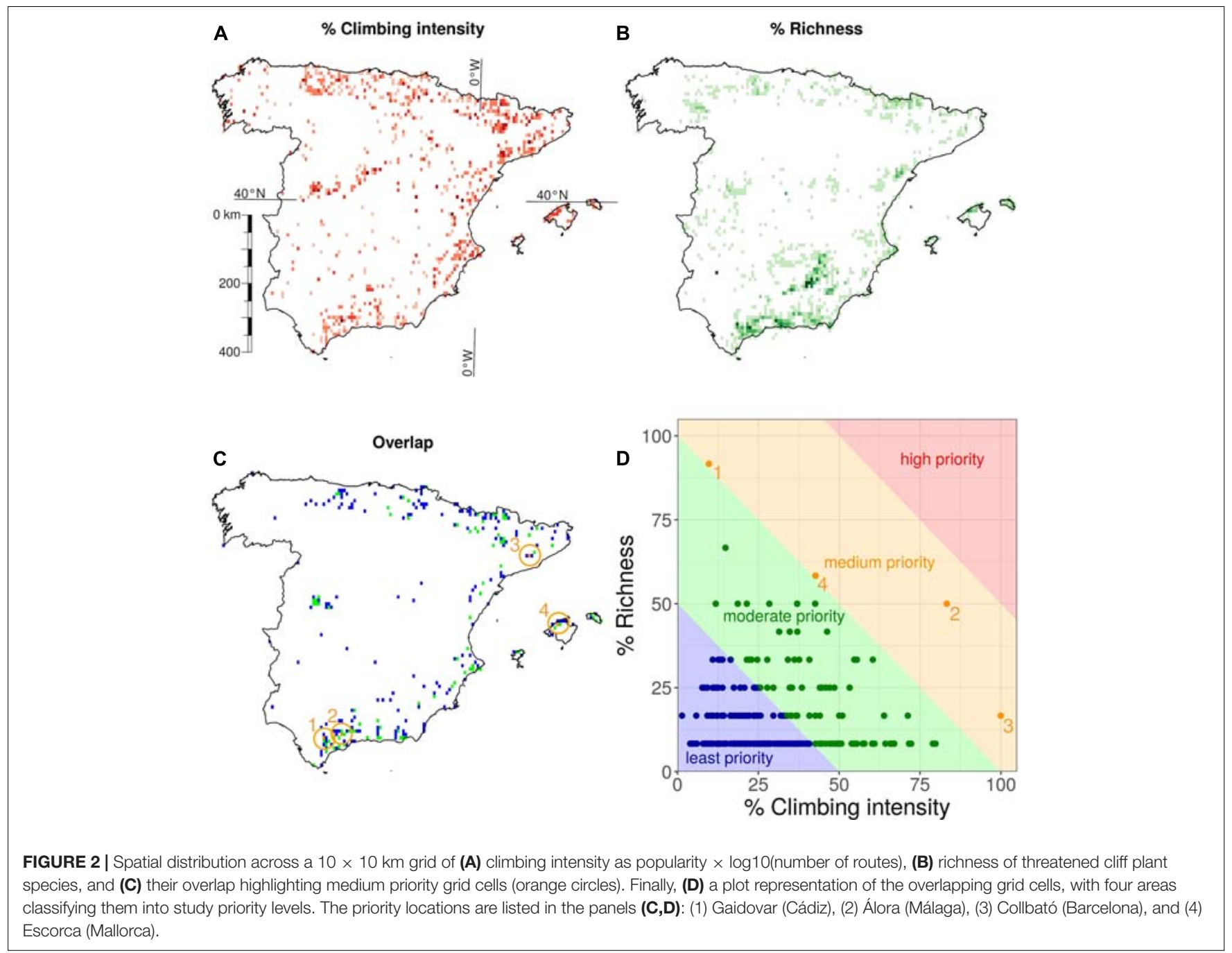

of the eight species whose distributions had a mean climbing intensity of over $50 \%$.

\section{Distribution of Rock-Climbing in Spain and Its Natural Protected Areas}

Given the proportion of protected land in Spain (27\%; Ministerio para la Transición Ecológica [MITECO], 2018; UNESCO, 2020) it is remarkable that such a high proportion of climbing routes occur inside NPAs (nearly 40\%, Figure 1). This is probably because protection is usually focused on forested or mountainous areas, where rocky outcrops do not allow human profitable activities (cropland, urban areas), but are precisely the only suitable areas for rock-climbing and other outdoor recreational activities (Granero and Baena, 2007). The overall distribution of climbing routes across IUCN protection categories mirrors the distribution of the protected land surface in Spain in those IUCN categories. That is, most of the protected land in Spain falls into IUCN category IV (82.6\%) and most of the climbing routes in protected land also occur in this category (ca. 90\%).
According to climbing styles, sport routes stand out as the most frequent. This reflects the recent growth in popularity of climbing as a sport, which is mainly opposed to rock-climbing as a technique within alpinism (Pérez-Brunicardi and ArchillaPrat, 2015). This conception of rock-climbing as a discipline of its own led to the establishment of practicing venues in nature (i.e., climbing crags) and indoor climbing gyms (later in history). These outdoor climbing locations (sometimes strikingly called sports facilities) ease access and engage increasingly higher numbers of participants (USDA, 2012) that, in turn, need more climbing locations in nature. Sport climbers repeatedly use the same stretches of the cliff face, which poses an evident threat to plant species (March-Salas et al., 2018). This is especially true in Spain, where the climate allows rock-climbing during most of the year and rock cliffs are spread around the country, not only in isolated mountain ranges (Myers et al., 2000; Di Castri and Mooney, 2012). This is the most likely explanation of why traditional routes are overrepresented in natural areas protected under IUCN category II (Figure 1B); due to the more adventurous spirit of traditional climbing, seeking more inaccessible natural areas (UIAA, 2000), some of which have 


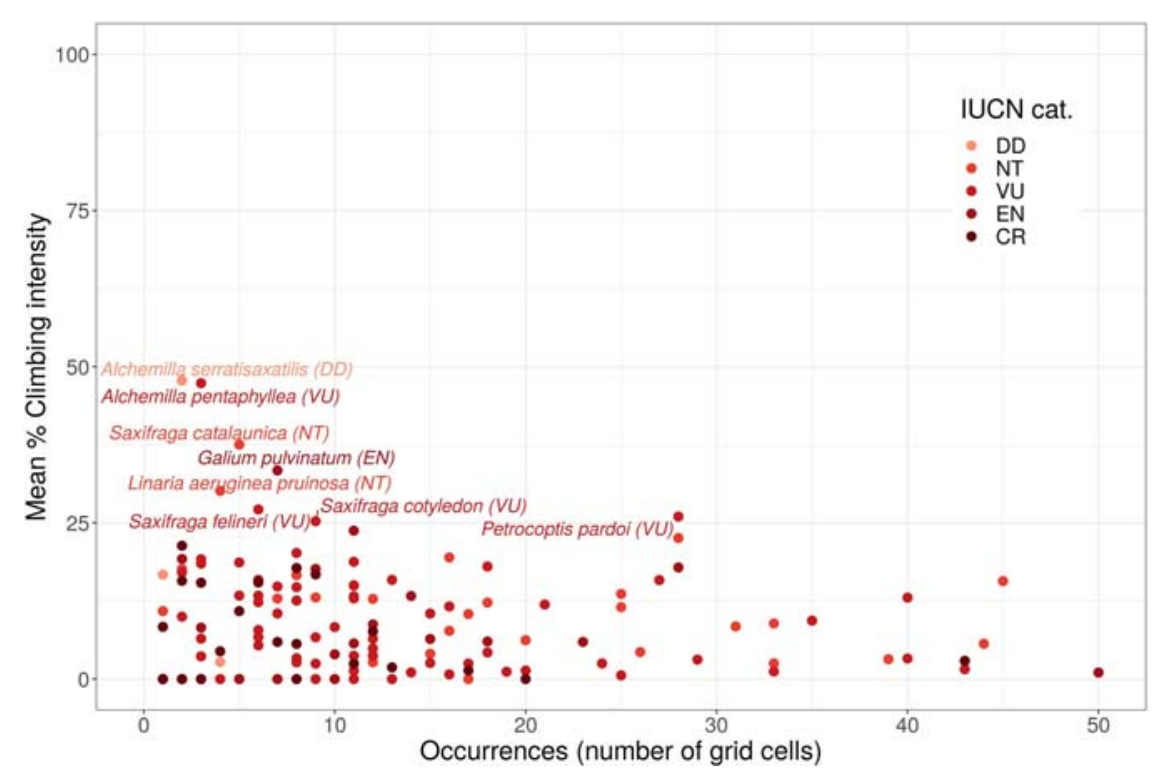

FIGURE 3 | Mean climbing intensity of the grid cells in which each threatened cliff plant species is present (occurrences as the number of grid cells). The color scale represents the levels of IUCN threat, the lightest color represents the lowest IUCN threat category, and the darker color the highest IUCN threat category.

likewise been protected as National Parks (IUCN category II). This could be due to the remarkable differences in regulation among NPAs (Lorite et al., 2017). Contrary to other situations in which conservation and sports meet, an association of environmentally aware climbers, the Spanish Federation for Mountaineering and Climbing (FEDME), and the National Parks Autonomous Organism are aware of the conflicting interests and are collaborating to develop evidence-based management practices and reiterate the importance of including climbing crags within NPAs (FEDME, 2018).

\section{Priority Study Locations}

Our results on the spatial distribution of threatened cliff plant species show that about 35\% of grid cells with climbing crags also harbor these species. Among them, the vast majority of the overlapping grid cells (98.6\%) was classified as least or moderate priority study locations since either the climbing intensity or percentage of threatened cliff species richness was lower than $50 \%$. This does not mean they do not deserve further study (or even protection), but that the low value of one or both variables is probably not enough to evaluate the effect of rock-climbing. In this sense, the primary in situ study efforts should be focused on the four locations (see orange symbols and area in Figures 2C,D). Moreover, here we highlight that all of these four locations are within the Mediterranean region of Spain, where most of the threatened species are located (Domínguez Lozano et al., 2003). The high vulnerability of Mediterranean habitats and biodiversity to climate change (Giorgi and Lionello, 2008; Newbold et al., 2020) might pose an extra conservation challenge regarding cliff habitats, which are already under pressure from rock-climbing.

Field-studies in priority locations should include continuous monitoring of cliff plants and implementing conservation strategies according to in situ research results. We found contrasting management strategies in Spanish NPAs with the same protection status, ranging from total climbing ban to the promotion of rock climbing. This denotes a positive effort in designing spatially specific and temporally dynamic plans for the conservation of the environment in climbing areas within NPAs (not only in Spain but other countries; e.g., Yosemite National Park in the United States, Peak District National Park in the United Kingdom, Montagu Nature Reserve in South Africa, Onkaparinga National Park in Australia, Saxon Switzerland National Park in Germany, etc.). Such location-specific yet temporally dynamic management avoids permanent climbing prohibition that may reduce tourism, and social wellbeing, even local economies (Caber and Albayrak, 2016; Koefod, 2019).

\section{Priority Study Species of Threatened Cliff Plant Species}

Comparing data for the priority grid cells and priority species, we conclude that, among the eight priority species with 25$50 \%$ climbing intensity, seven have Mediterranean distributions and four are considered species of special interest because, among their cell distributions, they include a study priority grid cell. They can be sorted into three levels: (1) S. catalaunica, $S$. cotyledon are high priority species (under mean climbing intensity of 37.5 and $25 \%$, respectively; present in five and nine grid cells, respectively) and both are present in a medium priority grid cell with the highest climbing intensity defined in this study (100\%). (2) G. pulvinatum (under mean climbing intensity of $33.4 \%$; among seven grid cells) is also of great study interest as it is present in a high priority grid cell, in which the climbing intensity is $83.3 \%$ (in the municipality of Álora, Málaga). Finally, (3) the species L. aeruginea subsp. pruinosa (under mean climbing 
intensity of $30.1 \%$; among four grid cells) is of less concern but is present in a medium priority grid cell with a climbing intensity of $42.7 \%$. Cliff-specialist species seem less vulnerable to the disturbance of rock-climbing than generalist species (MarchSalas et al., 2018). Thus, the strict-rupicolous nature of these four species may attenuate the pressure of the high climbing intensities found along their distributions. A more in-depth evaluation of the study locations may help to minimize the potential damage to these top-priority species, together with the rest of the 140 threatened species compiled in the present study and included in atlas and red books of threatened plant species for Spain (see Moreno-Saiz et al., 2003 for an overview).

A remarkable case within our study is the only species classified as endangered (EN), G. pulvinatum, which is present in seven grid cells with an average climbing intensity of $33.39 \%$. Bibliographic sources (Bañares et al., 2004, 2010; Blanca et al., 2011) proved that this species is indeed present in two locations confirming the accuracy of GBIF occurrences. Thus, a thorough evaluation of its populations is required.

Further field-research aimed at cliff plant species should include: (a) an assessment of the presence of endangered species in the cliff-faces where rock-climbing is practiced as well as in potential surrounding cliffs where new climbing routes can be opened. When the presence of an endangered species is confirmed, research should also undertake; (b) an exhaustive study using standardized methods on the effect of rock-climbing on its population biology (i.e., abundance/cover, stability of its pollination network, phenology, fitness, etc.). Finally, studies should also take into account, (c) long-term monitoring for a comprehensive follow up of the species' population dynamics along seasons and years (even individual's monitoring). This should be accompanied by a strong environmental awareness campaign by NPA authorities and climbers' associations aimed at climbers and a broader audience.

\section{Study Limitations and Future Directions}

This study identified a series of limitations that could produce skewed results that should be taken into account when designing conservation programs and management policies in the future. These limitations arise mainly from the data sources. First, data for climbing crags are incomplete. Despite we have compiled the existing information, some crags might be missing in our dataset. Second, the popularity of crags is based on expert-criteria. In the future, a climbers-frequency index could be designed based on field sociological data. Third, plant distribution data from GBIF is known to be incomplete or geographically imprecise, in this sense, alternative sources (e.g., literature and regional databases of threatened flora) and field surveys could be included.

Measuring the diversity of cliff plants by calculating richness is also most probably an oversimplification that could hide essential information on the conservation status of populations. A combination of several diversity indexes (based on field data) would probably aid a better understanding of the health of cliff plant species. Moreover, we only focus on measuring the diversity of threatened cliff plant species as the most sensitive component. Considering that generalist species can represent even the $70 \%$ of the plants present on the rocks of climbing crags (MarchSalas et al., 2018), future studies could broaden the scope of these analyses, including not only strict rupicolous species but also generalist ones.

In addition, the rasterization of data in this study also indirectly assumes that in each grid cell overlapping variables coexist (i.e., all rocky outcrops present in each grid cell are occupied by both plants and climbing routes). In the future, building maps of available rock cliff habitat would help correct for potential overestimation of the overlap of climbing and plant populations. Nevertheless, we used a conservative approach to summarize the intensity of climbing in each grid cell by selecting the highest climbing intensity of the present climbing crags. Again, further fieldwork is required to find more accurate ways of summarizing the climbing intensity of nearby climbing crags. All this being said, the results presented do show clear trends and provide a useful picture of the potential risk of rock-climbing for cliff environments in Spain.

\section{CONCLUDING REMARKS}

This is the first national-scale study on the potential risk of rockclimbing for cliff habitats and the first to analyze in advance (i.e., prior to the field study) the most informative areas and species for field studies examining the effects of rock-climbing. This spatial approach is an invaluable starting point to focus study efforts toward areas or species conservation. However, the findings provided by this study do not intend to be enough for driving management policies or changing current regulations. Nonetheless, this study helps prioritizing in situ follow up of potentially sensitive locations, designing future field research, and individual monitoring of identified priority species. Ultimately, the locations highlighted here could work as seminal research locations to test conservation strategies before applying them to other Mediterranean regions worldwide. This literature-based study urges researchers to implement exhaustive fieldwork that will improve our understanding of the current and long-term effects of rock-climbing on the cliff environment, specifically on Mediterranean rupicolous flora. The unprecedented popularity and growth of outdoor leisure-activities mean that it is imperative to further understand the potential risk to the environment. To conclude, this study lays the groundwork for finding a sustainable balance between the protection of these unique ecosystems and rock-climbing, fulfilling conservation criteria and the needs of society.

\section{DATA AVAILABILITY STATEMENT}

The raw data supporting the conclusions of this article will be made available by the authors, without undue reservation.

\section{AUTHOR CONTRIBUTIONS}

IdC-A conceived the study, and with the collaboration of MM-S and JL performed the final design of the work. IdC-A analyzed 
the data. All authors gathered and revised the data, and wrote and reviewed the manuscript.

\section{FUNDING}

We thank the National Geographic Society (Grant Numbers EC-50532R-18 and NGS-82734R-20), American Alpine Club (AAC), and Asociación Española de Ecología Terrestre (AEET) for supporting the studies

\section{REFERENCES}

Aedo, C., Buira, A., Medina, L., and Fernández-Albert, M. (2017). “The Iberian vascular Flora: richness, endemicity and distribution pattern," in Loidi J. 2017. The Vegetation of the Iberian Peninsula, ed. J. Loidi (Utrecht: Springer), 101130. doi: 10.1007/978-3-319-54784-8_4

American Alpine Club Report [AAC] (2019). State of Climbing. Available online at: https://aac-publications.s3.amazonaws.com/articles/State_of_Climbing Report_2019_Web.pdf (accessed February 5, 2021).

Attarian, A., and Keith, J. (2008). Climbing Management: A Guide to Climbing Issues and the Development of a Climbing Management Plan. Available online at: http://www.accessfund.org/ (accessed July 16, 2020).

Bañares, Á, Blanca, G., Guemes, J., Moreno, J. C., and Ortiz, S. (2004). Atlas y Libro Rojo de la flora Vascular Amenazada de España. Madrid: Ministerio de Medio Ambiente Medio Rural y Marino.

Bañares, A. ì, Blanca, G., Güemes, J., Moreno, J. C., and Ortiz, S. (2010). Atlas y Libro Rojo de la Flora Vascular Amenazada de Espanba. Adenda 2010. Direccioin General de Medio Natural y Polititica Forestal (Ministerio de Medio Ambiente, y Medio Rural y Marino)-Sociedad Espanbola de Biologiia de la Conservacioin de Plantas. Madrid: Ministerio de Medio Ambiente Medio Rural y Marino.

Blanca, G., Cabezudo, B., Cueto, M., Salazar, C., and Morales Torres, C. (2011). Flora vascular de Andalucía oriental (2. ${ }^{a}$ edición corregida y aumentada). Granada: Universidad de Granada.

Burgin, S., and Hardiman, N. (2012). Extreme sports in natural areas: looming disaster or a catalyst for a paradigm shift in land use planning? J. Environ. Plan. Manag. 55, 921-940. doi: 10.1080/09640568.2011.634228

Caber, M., and Albayrak, T. (2016). Push or pull? Identifying rock climbing tourists' motivations. Tour. Manag. 55, 74-84. doi: 10.1016/j.tourman.2016. 02.003

Castroviejo S. (1986-2019). Flora Iberica. Madrid: CSIC, Real Jardín Botánico.

Chamberlain, S., Boettiger, C., Ram, K., Barve, V., and Mcglinn, D. (2016). rgbif: Interface to the Global Biodiversity Information Facility API. R package version 0.9.3.

Chamberlain, S., Szoecs, E., Foster, Z., Arendsee, Z., Boettiger, C., Ram, K., et al. (2020). taxize: Taxonomic information from around the web. $\mathrm{R}$ package version 0.9.95.

Clark, P., and Hessl, A. (2015). The effects of rock climbing on cliff-face vegetation. Appl. Veg. Sci. 18, 705-715. doi: 10.1111/avsc.12172

Cordell, H. K. (2012). Outdoor Recreation Trends and Futures: A Technical Document Supporting the Forest Service 2010 RPA Assessment. General Techniocal Report SRS-150. Asheville, NC: U.S. Department of Agriculture Forest Service, Southern Research Station, 167. doi: $10.2737 /$ SRS-GTR- 150

Di Castri, F., and Mooney, H.A. (eds) (2012). Mediterranean Type Ecosystems: Origin and Structure, Vol. 7. Heidelberg: Springer Science \& Business Media.

Domínguez Lozano, F., Moreno Saiz, J. C., and Sainz Ollero, H. (2003). Rarity and threat relationships in the conservation planning of Iberian flora. Biodivers. Conserv. 12, 1861-1882. doi: 10.1023/A:1024110925948

FEDME (2018). Perfil de los Visitantes del Medio Natural. Catalonia: FEDME, 80.

Giorgi, F., and Lionello, P. (2008). Climate change projections for the Mediterranean region. Glob. Planet. Change 63, 90-104. doi: 10.1016/j. gloplacha.2007.09.005 that gave rise to this work. Project B1-RNM-163UGR18-Programa Operativo FEDER, 2018, partially funded this research.

\section{SUPPLEMENTARY MATERIAL}

The Supplementary Material for this article can be found online at: https://www.frontiersin.org/articles/10.3389/fevo.2021. 611362/full\#supplementary-material

Granero, A., and Baena, A. (2007). Importancia de los valores educativos de las actividades físicas en la naturaleza. Habilidad Motriz 29, 5-14. doi: 10.21500/ 20275846.240

Hanemann, B. (2000). Cooperation in the European Mountains: The Sustainable Managment of Climbing Areas in Europe. Available online at: http://www.loc. gov/catdir/enhancements/fy0666/2001369710-d.html (accessed July 16 2020).

Holzschuh, A. (2016). Does rock climbing threaten cliff biodiversity? - A critical review. Biol. Conserv. 204, 153-162. doi: 10.1016/j.biocon.2016.10.010

Koefod, C. (2019). Estimating the Economic Value of Rock Climbing in Smith Rock: An individual Travel Cost Approach. Ph.D. thesis. Ellensburg, WA: Central Washington University, 1212.

Larson, D. W., Matthes, U., and Kelly, P. E. (2000). Cliff ecology: Pattern and Process in Cliff Ecosystems. Cambridge: Cambridge University Press. doi: 10. 1017/CBO9780511525582

Lavergne, S., Garnier, E., and Debussche, M. (2003). Do rock endemic and widespread plant species differ under the leaf-heightseed plant ecology strategy scheme? Ecol. Lett. 6, 398-404. doi: 10.1046/j.1461-0248.2003.00456.x

Lionello, P., Malanotte-Rizzoli, P., Boscolo, R., Pinhas, A., Vincenz, A., Li, L., et al. (2006). "The Mediterranean climate: an overview of the main characteristics and issues," in Mediterranean Climate Variability, eds P. Lionello, P. MalanotteRizzoli, and R. Boscolo (Amsterdam: Elsevier), 1-26. doi: 10.1016/s15719197(06)80003-0

Lorite, J., Serrano, F., Lorenzo, A., Cañadas, E. M., Ballesteros, M., and Peñas, J. (2017). Rock climbing alters plant species composition, cover, and richness in Mediterranean limestone cliffs. PLoS One 12:e0182414. doi: 10.1371/journal. pone. 0182414

March-Salas, M., Moreno-Moya, M., Palomar, G., Tejero-Ibarra, P., Haeuser, E., and Pertierra, L. R. (2018). An innovative vegetation survey design in Mediterranean cliffs shows evidence of higher tolerance of specialized rock plants to rock climbing activity. Appl. Veg. Sci. 21, 289-297. doi: 10.1111/avsc. 12355

March-Salas, M., van Kleunen, M., and Fitze, P. S. (2019). Rapid and positive responses of plants to lower precipitation predictability. Proc. R. Soc. Lond. B. 286, 20191486. doi: 10.1098/rspb.2019.1486

Martos, E. (ed.) (2018). Dónde Escalar en España. Madrid: Ediciones Desnivel.

Médail, F., and Diadema, K. (2009). Glacial refugia influence plant diversity patterns in the Mediterranean Basin. J. Biogeogr. 36, 1333-1345. doi: 10.1111/j. 1365-2699.2008.02051.x

Ministerio para la Transición Ecológica [MITECO] (2018). Estrategia de Conservación y Lucha Contra las Amenazas de Plantas Protegidas en Ambientes Rupícolas. Madrid: Ministerio para la Transición Ecológica.

Ministerio para la Transición Ecológica [MITECO] (2020a). Espacios Naturales Protegidos (ENP_ES). Available online at: https://www.miteco.gob.es/eu/ biodiversidad/servicios/banco-datos-naturaleza/enp_dic19_p_tcm35- 195776. zip (accessed April 1, 2020).

Ministerio para la Transición Ecológica [MITECO] (2020b). Flora Vascular (AFA). Available online at: https://www.miteco.gob.es/es/biodiversidad/temas/ inventarios-nacionales/inventario-especies-terrestres/ieet_flora_vascular.aspx (accessed March, 31 2020).

Moreno-Saiz, J. C., Domínguez-Lozano, F., and Sainz-Ollero, H. (2003). Recent progress in conservation of threatened Spanish vascular flora: a critical review. Biol. Conserv. 113, 419-431. doi: 10.1016/s0006-3207(03)00128-9 
Myers, N., Mittermeier, R. A., Mittermeier, C. G., da Fonseca, G. A., and Kent, J. (2000). Biodiversity hotspots for conservation priorities. Nature 403, 853-858. doi: $10.1038 / 35002501$

National Biodiversity Strategy (2020). Biodiversity. Available online at: https:// biodiversity.europa.eu/countries/spain. (accessed July 22, 2020).

Newbold, T., Hudson, L. N., Hill, S., Contu, S., Lysenko, I., Senior, R. A., et al. (2015). Global effects of land use on local terrestrial biodiversity. Nature 520, 45-50. doi: 10.1038/nature14324

Newbold, T., Oppenheimer, P., Etard, A., and Williams, J. J. (2020). Tropical and Mediterranean biodiversity is disproportionately sensitive to land-use and climate change. Nat. Ecol. Evol. 4, 1630-1638. doi: 10.1038/s41559-020-01303-0

Pérez-Brunicardi, D., and Archilla-Prat, M. T. (2015). "Outdoor sport learning, the ecological model," in Retos del Montañismo en el Siglo XXI, eds P. Allueva Torres, and J. M. Nasarre Sarmiento (Zaragoza: CIMA), 40-49.

R Development Core Team (2019). R: A Language and Environment for Statistical Computing. Vienna: R Foundation for Statistical Computing.

Schmera, D., Rusterholz, H., Baur, A., and Baur, B. (2018). Intensitydependent impact of sport climbing on vascular plants and land snails on limestone cliffs. Biol. Conserv. 224, 63-70. doi: 10.1016/j.biocon.2018.05.012

Strumia, S., Buonanno, M., Aronne, G., Santo, A., and Santangelo, A. (2020). Monitoring of plant species and communities on coastal cliffs: Is the use of unmanned aerial vehicles suitable? Diversity 12, 6-9. doi: 10.3390/d12040149

UIAA (2000). To Bolt or Not to Be. Available online at: https://www.theuiaa.org/ documents/declarations/11.3._To_bolt_or_not_to_be.pdf (accessed July 22, 2020).

UIAA (2014). UIAA Recommendations on the Preservation of Natural Rock. Bern: UIAA.
UNESCO (2020). Biosphere Reserves. Availanle online at: https://en.unesco.org/ biosphere (accessed July 22, 2020).

USDA (2012). Outdoor Recreation Trends and Futures. Washington, DC: USDA, 184.

Vera, J.A. (ed.) (2004). Geología de España. Madrid: SGE-IGME.

Vitousek, P. M., Mooney, H. A., Lubchenco, J., and Melillo, J. M. (1997). Human domination of Earth's ecosystems. Science 277, 494-499. doi: 10.1126/science. 277.5325.494

Waller, J., and Grosjean, M. (2019). Downloading Occurrences from a Long List of Species in $R$ and Python - GBIF Data Blog. Available online at: https://datablog.gbif.org/post/downloading-long-species-lists-on-gbif/ (accessed June 29, 2020).

Watson, J. E. M., Dudley, N., Segan, D. B., and Hockings, M. (2014). The performance and potential of protected areas. Nature 515, 67-73. doi: 10.1038/ nature 13947

Conflict of Interest: IdC-A is a climber and a conservationist.

The remaining authors declare that the research was conducted in the absence of any commercial or financial relationships that could be construed as a potential conflict of interest.

Copyright (c) 2021 deCastro-Arrazola, March-Salas and Lorite. This is an openaccess article distributed under the terms of the Creative Commons Attribution License (CC BY). The use, distribution or reproduction in other forums is permitted, provided the original author(s) and the copyright owner(s) are credited and that the original publication in this journal is cited, in accordance with accepted academic practice. No use, distribution or reproduction is permitted which does not comply with these terms. 